\title{
Two Useful Safe Products for Maintaining Healthy Vagina and Prevention of Infection with Human Papilloma Virus leading to Carcinoma of Cervix
}

\section{Talwar GP* and Jagdish C Gupta}

Talwar Research Foundation, India

*Corresponding author: Talwar GP, Talwar Research Foundation, E-8, Neb Valley, New Delhi-110068, India, Email: gptalwar@gmail.com

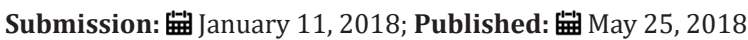

\section{Introduction}

We developed a Poly-herbal formulation named as BASANT, which has remarkable properties of inhibiting a wide spectrum of genital infections. It inhibits all WHO (World Health Organization) strains of $N$. gonorrhoeae including those strains resistant to Penicillin, Tetracycline. Nalidixic acid and Ciprofloxacin [1] it has pronounced inhibitory action against Candida glabarata, Candida albicans, and Candida tropicalis isolated from women with vulvovaginal candidacies, including strains resistant to azole drugs and amphotericin [1]. BASANT has inhibitory action on free as well as within cells contained Chlamydia trachomatis [2] BASANT inhibits HIV-1 at the early stage of infection. What is more, it is effective against HIV strains employing both CCR5 and CXCR4 receptors for entry into blood cells. It is effective against primary isolates of different clades [3]. BASANT is composed of highly purified Curcumin (diferuloyl methane), extracts of Amla (Emblica officinalis), Aloe vera (Aloe barbadensis) and Azadirachta indica (Neem) leaves along with pharmacopoeially approved excipients and preservatives. It is packaged in easily dispersing cellulose capsules, which can be inserted by women in the vagina without any difficulty. These are fully safe and non-irritating. The only disadvantage is the yellow colour of Curcumin, which can be easily taken care of by using vaginal pads.

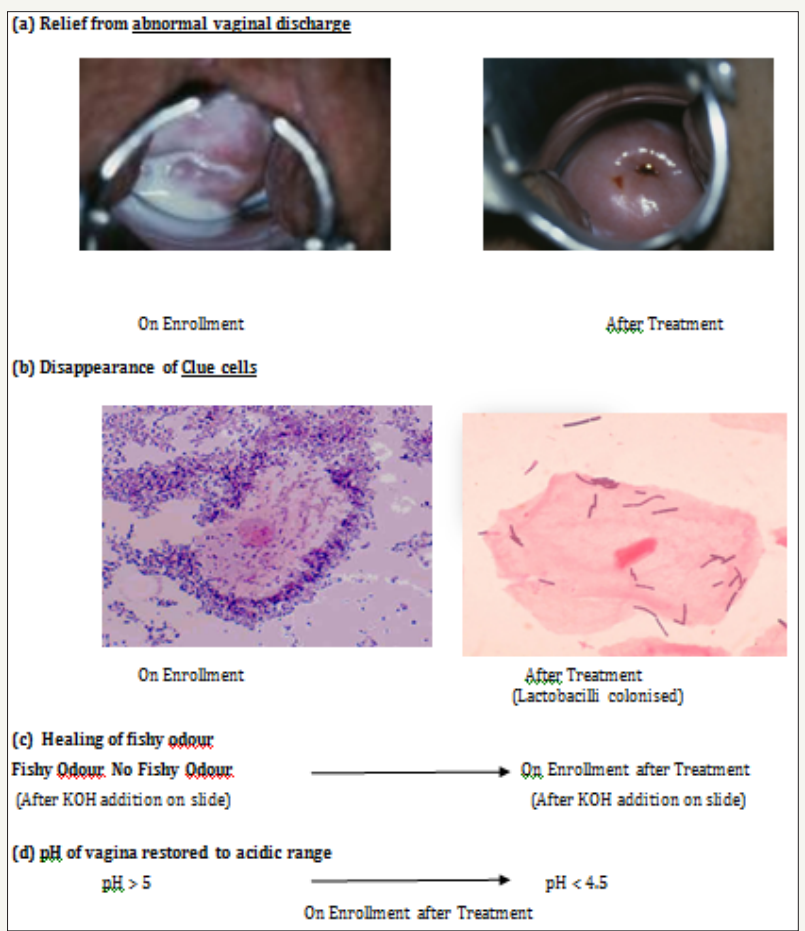

Figure 1: An illustrative representation of a typical woman receiving treatment with NAUROZ, a combination of BASANT plus Pro-vag-Health. 
Table 1: Summary of results of treatments with either Probiotics, BASANT or a combination of BASANT and Probiotics to cure Vaginosis and restore reproductive health [5].

\begin{tabular}{|c|c|c|c|c|}
\hline Group Name & Women Enrolled & Women Improved & P value Comparison with Placebo & $\begin{array}{c}\text { P value Comparison with } \\
\text { BASANT+Probiotics }\end{array}$ \\
\hline Probiotics & 20 & $13(65 \%)$ & $\mathrm{P}<0.001$ & $\mathrm{P}=0.04$ \\
\hline BASANT & 20 & $14(70 \%)$ & $\mathrm{P}<0.001$ & $\mathrm{P}=0.09$ \\
\hline BASANT+Probiotics (NAUROZ) & 20 & $19(95 \%)$ & $\mathrm{P}<0.001$ & - \\
\hline Placebo & 20 & $1(5 \%)$ & - & $\mathrm{P}<0.001$ \\
\hline
\end{tabular}

The second product is Pro-vag-Health, a combination of 3 meritorius strains of Probiotics. These are Lactobacillus fermentum TRF\# 36, Lactobacillus salivarius TRF\#30 and Lactobacillus gasserei TRF\#8. All of these make and secrete high amounts of lactic acid. As reported by us elsewhere, the amount of Lactic acid made and secreted by different strains, even within the same species, varies [4]. Hence strains secreting high amount of lactic acid, are valuable. Furthermore hydrophobicity of various strains differs. Strains chosen by us have high hydrophobicity, enabling their easy colonization in the vagina. All of them have the enzyme arginine deiminase, which prevents the production of foul odour derivatives. We conducted a Phase II trial in 80 women suffering from recurring episodes of Vaginosis. On randomized basis, 20 women were given BASANT every night for 7 days, 20 received the 3 selected strains of Probiotics, 20 received a combination of the two, namely BASANT plus the 3 Probiotics and 20 women employed placebo. The result is summarised in Table 1. Also shown in Figure 1 are observations on a typical patient cured of Vaginosis [5].

\section{Comparison with fisher's exact test}

The combined use of BASANT and Pro-vag-Health (3 Probiotics) cured 19 out of 20 women receiving these. No antibiotic so far reported in world literature has such high efficacy.

\section{Elimination of Human Papilloma 16 Virus from Infected Cervical Cells}

BASANT inhibits the entry of HPV 16 in Hela cells as observed by Dr. Schiller at NIH, Bethesda [1]. What is amazing is it's ability to eliminate HPV16 from infected cervical cells on path of progression to carcinoma of cervix. A trial was conducted at the Jawaharlal Nehru Medical College, Aligarh along with Institute of Cytology and Preventive Oncology of the Indian Council of medical Research. One hundred fifty nine women were examined clinically by visual inspection of cervix and by staining with acetic acid. Pap smears were prepared from the cervical scraps collected from the ectocervical region and endo-cervical canal. Thirty five women, who had inflammatory cervix and abnormal Pap smear, were enrolled. Out of these, 19 women were diagnosed positive for HPV-16. Eleven women out of these 19 gave written consent to undergo intra-vaginal treatment with BASANT. They were asked to insert a capsule containing $245 \mathrm{mg}$ of BASANT in the vagina every night before going to bed for 30 days, excluding the days of menstruation. Table 2 summarizes the observations.
Table 2: Pre and post treatment with BASANT of HPV-16 positive patients [6].

\begin{tabular}{|c|c|c|c|c|}
\hline S. No & Age & Parity & $\begin{array}{c}\text { HPV-16 } \\
\text { Pre-Treatment }\end{array}$ & $\begin{array}{c}\text { HPV-16 } \\
\text { Post-Treatment }\end{array}$ \\
\hline 1 & 42 & $3+0$ & $+\mathrm{VE}$ & NEGATIVE \\
\hline 2 & 27 & $4+0$ & $+\mathrm{VE}$ & NEGATIVE \\
\hline 3 & 35 & $3+0$ & $+\mathrm{VE}$ & NEGATIVE \\
\hline 4 & 28 & $1+1$ & $+\mathrm{VE}$ & NEGATIVE \\
\hline 5 & 45 & $3+0$ & $+\mathrm{VE}$ & NEGATIVE \\
\hline 6 & 35 & $4+0$ & $+\mathrm{VE}$ & NEGATIVE \\
\hline 7 & 30 & $2+1$ & $+\mathrm{VE}$ & NEGATIVE \\
\hline 8 & 45 & $2+0$ & $+\mathrm{VE}$ & NEGATIVE \\
\hline 9 & 38 & $5+2$ & $+\mathrm{VE}$ & NEGATIVE \\
\hline 10 & 35 & $3+1$ & $+\mathrm{VE}$ & NEGATIVE \\
\hline 11 & 38 & $3+1$ & $+\mathrm{VE}$ & NEGATIVE \\
\hline
\end{tabular}

Number of patients screened for HPV DNA: 159; Number of patients positive for HPV-16: 19; Intravaginal BASANT given with written consent to $11 \mathrm{HPV}$ positive patients accepting to take BASANT; All turning HPV-16 negative after using intravaginaly BASANT.

It is clear from the observations that every woman (11/11) who used BASANT for 30 nights had no HPV-16 in their cervical cells. Abnormal Pap smear returned to normalcy in each case [6]. Thus BASANT can be extremely helpful to women to get rid of infection of HPV-16 in their cervical cells at early stages of CIN I, II, as long as the virus is not integrated in the host genome.

\section{Acknowledgement}

The work received research grants from the Department of Biotechnology, Govt of India and the Indian Council of Medical Research, New Delhi.

\section{References}

1. Talwar GP, Dar SA, Rai MK, Reddy KV, Mitra D, et al. (2008) A novel Polyherbal microbicide with inhibitory effect on bacterial, fungal and viral genital pathogens. Int J Antimicrob Agents 32(2): 180-185.

2. Bhengraj AR, Dar SA, Talwar GP, Mittal A (2008) Potential of a novel polyherbal formulation BASANT for prevention of Chlamydia trachomatis infection. Int J Antimicrob Agents 32(1): 84-88. 
3. Maselko MB, Joshic RS, Prescott M, Talwar GP, Kulkarni S, et al. (2014) Basant, a polyherbal topical microbicide candidate inhibits different clades of both ccr5 and cxcr4 tropic, lab-adapted and primary isolates of human immunodeficiency virus-1 in vitro infection. J Virol Antivir Res $3(4): 3$.

4. Garg KB, Ganguli I, Ram Das, Kriplani A, Lohiya NK, et al. (2009) Metabolic properties of lactobacilli in women experiencing recurring episodes of bacterial vaginosis with vaginal $\mathrm{pH} \geq 5$. Eur J clin Microbiol Infect Dis 29(1): 123-125.
5. Talwar GP, Kavita Garg, Atrey N, Singh P, Gaur J, et al. (2015) A safe wide spectrum polyherbal microbicide and three meritorious strains of probiotics for regressing infections and restoration of vaginal health (Regression of Vaginosis with BASANT and Probiotics). J Women's Health Care 4(5): 256.

6. Talwar GP, Sharma R, Singh S, Das BC, Bharti AC, et al. (2015) BASANT, a polyherbal safe microbicide eliminates HPV-16 in women with early cervical intraepithelial lesions. Journal of Cancer Therapy 6(14): 11631166.

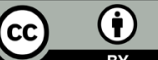

Creative Commons Attribution 4.0 International License

For possible submissions Click Here
Submit Article

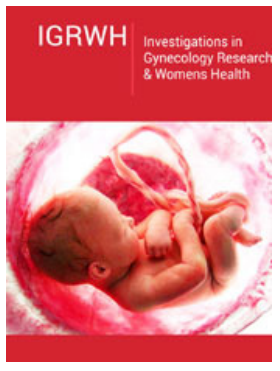

Investigations in Gynecology Research \& Womens Health

\section{Benefits of Publishing with us}

- High-level peer review and editorial services

- Freely accessible online immediately upon publication

- Authors retain the copyright to their work

- Licensing it under a Creative Commons license

- Visibility through different online platforms 